\title{
Synthesis of a [5] Helicene-Based Chiral Polymer
}

\author{
Janet M Olseon and Thieo E Hogen Esch* \\ Department of Chemistry, Loker Hydrocarbon Research Institute, USA
}

*Corresponding author: Thieo E Hogen Esch, Loker Hydrocarbon Research Institute and Department of Chemistry, Los Angeles,

CA90089-1661, USA

ARTICLE INFO

Received: 幽 April 18, 2019

Published: April 29, 2019

Citation: Janet M O,Thieo E H E. Synthesis of a [5] Helicene-Based Chiral Polymer. Biomed J Sci \& Tech Res 17(3)2019. BJSTR. MS.ID.003019.

\begin{abstract}
A copolymer precursor, an alkoxy-functionalized 3,12-diethyenyl[5] helicene, was prepared in seven consecutive steps. A $\operatorname{Pd}(0)$-catalyzed reaction between this helicene derivative and p-diiodobenzene gave polymer 11 , which is soluble in many common organic solvents. Peaks in the UV spectrum of 11 are shifted to the red when compared with the spectrum of monomeric analogue 12, presumably because of extended conjugation between the helicene comonomers and the aryl connector units.
\end{abstract}

\section{Introduction}

Helicenes are polycyclic structures composed of $n$ ortho-fused aromatic rings, where $\mathrm{n}$ refers to the number of rings. When $\mathrm{n}$ reaches five or more, the molecule experiences steric repulsion between the terminal rings, causing the molecule to twist into a helix [1]. However, some phenanthrenes and benzophenanthrene were optically resolved and conformationally stable since the early days of helicene chemistry ( $n=3$ and 4 ).[ref] The inherent chirality of these molecules gives rise to large optical rotations (several thousand degrees) [2] and high circular dichroism values [3]. As chiral conjugated compounds, helicenes and their derivatives have found applications, including: semiconductors [4,5] organic light-emitting diodes (OLEDs) [6,7] and nonlinear optical (NLO) materials [8]. The above reports have all dealt with helicenes on the molecular level, i.e. small molecules. The synthesis of the corresponding polymeric helicenes is well known not to be feasible as the steric congestion has been shown to prevent the formation of helicenes longer than [14] helicene [9] However, the synthesis of [16] helicenes containing alternating copolymers having a vinylene [10] or aryl [11] connector is possible [11].

Such structures could feature both extended partial conjugation and the helicene chirality. Pu and co-workers synthesized many polymers in which 1,1'-binaphthyls alternated with aryl groups to produce structures with main-chain chirality [12]. However, extended conjugation across the binaphthyl 1,1'-moiety in a polymer is essentially absent given the large dihedral angle between the two naphthyl groups [13]. Unlike 1,1'-binaphthalene, partial conjugation in helicenes can extend across the entire molecule [11]. Moreover, copolymerization with a benzylidine or similar arylidene connector group should allow increased delocalization. However, helicenes with polymerization potential represent a more synthetically challenging target $[11,14,15]$. Hence, the synthesis of new and more effective helicene polymer precursors is of interest. The route toward a new helicene monomer was inspired by a 2007 report by Kamikawa and co-workers. The focus of this work was the one-step conversion of Z,Z-stilbenes into helicenes, via a palladiummediated C-H arylation reaction (Scheme 1) [16].

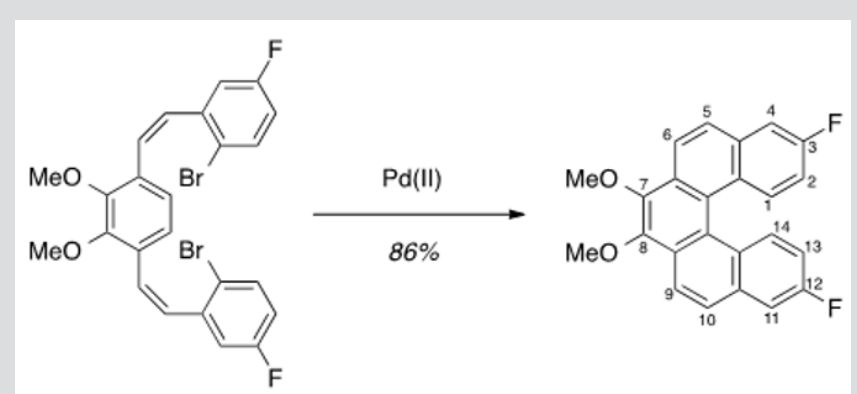

Scheme 1: Conversion of a Z,Z-stilbene into a [5]helicene via a $\mathrm{C}-\mathrm{H}$ arylation reaction.

Upon replacement of the fluorine in this reported helicene with an acetylene group, reaction with an aryl halide to generate a fully conjugated polymer under Sonogashira reaction conditions would be possible $[17,18]$. While the direct conversion of aryl fluorides into acetylenes is difficult, replacing fluorine with chlorine should make this reaction possible [19]. The methoxy groups on this helicene 
offer another opportunity for modification. Although weaker than for angular or planar pPolymers, $\pi-\pi$ interactions in helicenes render polymers insoluble in the common organic solvents used for processing and characterization. This can be addressed by including solubilizing groups, such as long alkyl chains [20]. Cleavage of the methyl ether, followed by alkylation with a longer chain will help to ensure that the resulting polymer will stay dissolved during its polymerization and subsequent processing, if needed. Additionally, the methoxy functional group serves as an electron-donor (D). The general $D-\pi-A$ (where $\pi$ is a conjugated linker, and A is an electronacceptor) structure has been determined to be effective in NLO polymers [21] and is also desirable for modification of electronic properties through tuning of the band gap [22].

An aryl group functionalized with A groups and then polymerized with a D-containing helicene could give an extended structure of these D- $\pi-A$ units. Here we report our route toward helicene derivative 1 . However, the racemization barrier for [5] helicene (24.1 kcal/mol at $\left.27{ }^{\circ} \mathrm{C}\right)$ [23] is low enough that it racemizes at room temperature within a few hours [24]. Because of this, the synthesis of a [5] helicene-based chiral (but not necessarily configurationally stable) polymer is not the main objective, but rather, a demonstration of a viable synthetic route.

\section{Experimental Section}

All reactions, unless otherwise noted, were conducted using commercially available solvents and reagents as received, without additional purification, in ordinary glassware under an inert argon atmosphere. Veratrole and TEA were distilled after being stirred over $\mathrm{CaH}_{2}$ for several hours. Dry solvents, such as: DCM, DMF, and THF were obtained from a DriSolv® bottle. $1 \mathrm{H}$ and $13 \mathrm{C}$ NMR spectra were recorded on Mercury 400 or Varian 400-MR (400 MHz) NMR spectrometers, using residual ${ }^{1} \mathrm{H}$ or ${ }^{13} \mathrm{C}$ signals of deuterated solvents as internal reference standards. Reactions were monitored by TLC carried out on $0.200 \mathrm{~mm}$ analytical layer Baker-flex $®$ plates using UV light $(254 \mathrm{~nm})$ as the visualizing agent. Silica gel (60 ̊, 40-63 $\mu$ m; Alfa Aesar) was used as a sorbent for flash column chromatography.

\section{2,3-Dimethoxy-1,4-dicarbaldehyde (5)}

TMEDA ( $37.5 \mathrm{ml}, .250 \mathrm{~mol}$ ) was added to a solution of veratrole $(6.37 \mathrm{ml}, .0500 \mathrm{~mol})$ in diethyl ether (DEE) $(250 \mathrm{ml})$ [3]. The reaction mixture was cooled to $-78{ }^{\circ} \mathrm{C}$, and n-butyllithium $2.5 \mathrm{M}$ in hexanes $(100 \mathrm{ml}, .250 \mathrm{~mol})$ was added over $10 \mathrm{~min}$. The solution was allowed to warm to rt, heated to reflux, and allowed to stir for $16 \mathrm{~h}$. The solution was then cooled to $-78^{\circ} \mathrm{C}$ for the addition of DMF (19.3 $\mathrm{mL}, 0.250 \mathrm{~mol}$ ), followed by warming to rt and stirring for $4 \mathrm{~h}$. Finally, the $200 \mathrm{ml}$ of water was added, followed by the addition of $3 \mathrm{M} \mathrm{HCl}$ to neutralize the solution. The organic layer was separated, and the aqueous layer was extracted using three $500 \mathrm{ml}$ portions of DEE. The combined organic layers were washed with saturated aqueous $\mathrm{NaHCO}_{3}$, water, and brine, followed by drying over $\mathrm{Na}_{2} \mathrm{SO}_{4}$ and concentration under reduced pressure. Purification by flash column chromatography using 25\% EtOAc/hexanes as eluent, followed by recrystallization from $10 \%$ toluene/hexanes afforded a pale yellow solid (3.31 g, 34\%). TLC: $25 \%$ EtOAc/hexanes, $\mathrm{Rf} \approx$ 0.5. Mp 98-100 ${ }^{\circ} \mathrm{C} .{ }^{1} \mathrm{H}$ NMR (400 MHz, CDCl3) $\delta 10.44(\mathrm{~s}, 2 \mathrm{H}), 7.62$ (s, 2H), 4.05 (s, 6H). 13C NMR (101 MHz, $\left.\mathrm{CDCl}_{3}\right) \delta 189.37,156.79$, $134.36,122.98,62.61$.

\section{2-Bromo-5-chlorobenzyl)triphenylphosphonium bromide} (3)

1-Bromo-2-(bromomethyl)-4-chloro-benzene $\quad(2.50$ g, 8.79 $\mathrm{mmol})$ and triphenylphosphine (2.31 g, $8.79 \mathrm{mmol})$ were brought up in DMF ( $9 \mathrm{ml}$ ) and allowed to stir at reflux for $3 \mathrm{~h} .1,2$ The mixture was allowed to cool to rt and filtered to collect the product, which was washed with cold toluene, followed by cold hexanes. The product was obtained as a colorless solid (4.73 g, 98\%). Mp > 250 ${ }^{\circ} \mathrm{C} .{ }^{1} \mathrm{H}$ NMR (400 MHz, $\mathrm{CDCl}_{3}$ ) $\delta 7.85-7.50(\mathrm{~m}, 15 \mathrm{H}), 7.47$ (q, J = 2.6 $\mathrm{Hz}, 1 \mathrm{H}), 7.30$ (d, $J=8.5 \mathrm{~Hz}, 1 \mathrm{H}), 7.11(\mathrm{dt}, J=8.8,2.6 \mathrm{~Hz}, 1 \mathrm{H}), 5.83$ $(\mathrm{d}, J=15.0 \mathrm{~Hz}, 2 \mathrm{H}) .{ }^{13} \mathrm{C}$ NMR (101 MHz, CDCl3) $\delta 135.39$ (d, $J_{\mathrm{PC}}=3.1$ $\mathrm{Hz}), 134.53\left(\mathrm{~d}, J_{\mathrm{PC}}=10.0 \mathrm{~Hz}\right), 133.95\left(\mathrm{~d}, J_{\mathrm{PC}}=3.4 \mathrm{~Hz}\right), 133.04\left(\mathrm{~d}, J_{\mathrm{PC}}=\right.$ $4.9 \mathrm{~Hz}), 130.44\left(\mathrm{~d}, J_{\mathrm{PC}}=12.8 \mathrm{~Hz}\right), 129.95\left(\mathrm{~d}, J_{\mathrm{PC}}=8.8 \mathrm{~Hz}\right), 125.18(\mathrm{~d}$, $\left.J_{\mathrm{PC}}=6.7 \mathrm{~Hz}\right), 117.50\left(\mathrm{~d}, J_{\mathrm{PC}}=86.0 \mathrm{~Hz}\right), 31.17\left(\mathrm{~d}, J_{\mathrm{PC}}=48.6 \mathrm{~Hz}\right)($ two peaks are not resolved).

\section{1,4-Bis[(1Z)-2-(2-bromo-5-chlorophenyl)ethenyl]-2,3- dimethoxybenzene (6)}

A solution of 5 (1.06 g, $5.45 \mathrm{mmol})$ and $3(6.56 \mathrm{~g}, 12.0 \mathrm{mmol})$ in THF ( $44 \mathrm{ml}$ ) was cooled to $0{ }^{\circ} \mathrm{C}[4]$. Potassium tert-butoxide (1.46 $\mathrm{g}, 12.4 \mathrm{mmol})$ dissolved in water $(4.4 \mathrm{ml})$ was added, dropwise, followed by warming to $\mathrm{rt}$ and stirring for $30 \mathrm{~min}$. The resulting mixture was partitioned between EtOAc and water and extracted with EtOAc. The combined organic layers were washed with brine, dried over $\mathrm{Na}_{2} \mathrm{SO}_{4}$, and concentrated under reduced pressure. Purification by flash column chromatography using 10\% EtOAc/ hexanes as eluent, followed by recrystallization from 10\% toluene/ hexanes afforded a colorless solid (2.10 g, 68\%). TLC: 14\% EtOAc/ Hexanes, $\mathrm{R}_{\mathrm{f}} \approx 0.7$. Mp 114-116 ${ }^{\circ} \mathrm{C} .{ }^{1} \mathrm{H}$ NMR (400 MHz, CDCl3) $\delta 7.47$ (d, $J=8.5 \mathrm{~Hz}, 2 \mathrm{H}$ ), 7.10 (d, $J=2.6 \mathrm{~Hz}, 2 \mathrm{H}$ ), 7.02 (ddd, $J=8.6,2.6$, $0.6 \mathrm{~Hz}, 2 \mathrm{H}), 6.82$ (d, $J=12.1 \mathrm{~Hz}, 2 \mathrm{H}), 6.58$ (d, $J=12.0 \mathrm{~Hz}, 2 \mathrm{H}), 6.50$ (s, 2H), 3.84 (s, 6H). 13C NMR (101 MHz, $\mathrm{CDCl}_{3}$ ) $\delta 151.62,139.51$, $133.83,133.04,130.35,130.33,129.16,128.78,127.38,124.37$, $121.73,61.07$.

\section{8,13-Dichloro-3,4-dimethoxydibenzo[c, g]phenanthrene (7)}

$\mathrm{Pd}(\mathrm{OAc})_{2}(78.7 \mathrm{mg}, 0.351 \mathrm{mmol}), \mathrm{K}_{2} \mathrm{CO}_{3}(0.972 \mathrm{~g}, 7.03 \mathrm{mmol})$, $\mathrm{Ag}_{2} \mathrm{CO}_{3}(0.485 \mathrm{~g}, 1.76 \mathrm{mmol}), \mathrm{PCy}_{3} \cdot \mathrm{HBF}_{4}(0.277 \mathrm{~g}, 0.703 \mathrm{mmol})$, and 2.96 (2.00 g, $3.51 \mathrm{mmol}$ ) were brought up in DMA (66.8 $\mathrm{ml}$ ) and allowed to stir at $120^{\circ} \mathrm{C}$ for $16 \mathrm{~h}$ [4]. Upon completion, the solution was cooled to rt and filtered through a pad of Celite to remove insoluble salts. The filtrate was concentrated under reduced pressure and purified by flash column chromatography using $20 \%$ DCM/hexanes as eluent to afford a pale yellow solid (0.900 g, 63\%). 
TLC: $75 \%$ DCM/hexanes, $\mathrm{R}_{\mathrm{f}} \approx 0.7 . \mathrm{Mp} 231-23{ }^{\circ} \mathrm{C} .1 \mathrm{H}$ NMR $(400$ $\mathrm{MHz}, \mathrm{CDCl}_{3}$ ) $\delta 8.31(\mathrm{~d}, \mathrm{~J}=8.8 \mathrm{~Hz}, 2 \mathrm{H}), 8.27(\mathrm{~d}, \mathrm{~J}=9.2 \mathrm{~Hz}, 2 \mathrm{H}), 7.92(\mathrm{~d}$, $\mathrm{J}=2.1 \mathrm{~Hz}, 2 \mathrm{H}), 7.86(\mathrm{~d}, \mathrm{~J}=8.9 \mathrm{~Hz}, 2 \mathrm{H}), 7.21(\mathrm{dd}, \mathrm{J}=9.0,2.3 \mathrm{~Hz}, 2 \mathrm{H})$, 4.13 (s, 6H). 13C NMR (101 MHz, CDCl3) $\delta 145.32,133.21,131.76$, 130.39, 128.98, 128.72, 126.97, 126.82, 125.40, 124.15, 121.24, 61.32 .

\section{8,13-Dichlorodibenzo[c,g]phenanthrene-3,4-diol (8)}

A solution of 2.107 (0.603 g, $1.48 \mathrm{mmol})$ in DCM (16 ml) was cooled to $-78^{\circ} \mathrm{C}$ for dropwise addition of $1.0 \mathrm{M} \mathrm{BBr}_{3}$ in DCM $(3.7 \mathrm{ml}$, $3.70 \mathrm{mmol}$ ) [5,6]. After $30 \mathrm{~min}$, the reaction was allowed to warm to $\mathrm{rt}$ and stirred for $16 \mathrm{~h}$. The mixture was then cooled to $0{ }^{\circ} \mathrm{C}$ and quenched with water, followed by extraction of the aqueous layer with DCM. The combined organic layers were washed with brine, dried over $\mathrm{Na}_{2} \mathrm{SO}_{4}$, and concentrated under reduced pressure. Purification by flash column chromatography using 20\% hexanes/ DCM as eluent afforded a red solid (0.320 g, 57\%). TLC: $33 \%$ hexanes/DCM, $\mathrm{R}_{\mathrm{f}} \approx 0.5 \mathrm{Mp}>250{ }^{\circ} \mathrm{C} .1 \mathrm{H} \mathrm{NMR}\left(400 \mathrm{MHz}, \mathrm{CDCl}_{3}\right) \delta$ $8.20(\mathrm{~d}, J=8.4 \mathrm{~Hz}, 2 \mathrm{H}), 7.98-7.90(\mathrm{~m}, 4 \mathrm{H}), 7.40-7.28(\mathrm{~m}, 4 \mathrm{H}) .13 \mathrm{C}$ NMR (101 MHz, CDCl3) $\delta 182.73,138.35,137.16,135.86,130.22$ $129.57,128.80,128.50,127.67,127.63,124.91$.

\section{8,13-Dichloro-3,4-bis[(2-ethylhexyl)oxy]dibenzo[c,g] phenanthrene (9)}

To a solution of $8(0.228 \mathrm{~g}, 0.601 \mathrm{mmol}), \mathrm{K}_{2} \mathrm{CO}_{3}(0.498 \mathrm{~g}, 3.61$ $\mathrm{mmol}$ ), and dibenzo-18-crown-6 (0.0220 g, $0.0601 \mathrm{mmol})$ in DMF ( $4 \mathrm{ml})$, 2-ethylhexyl bromide $(0.640 \mathrm{ml}, 4.81 \mathrm{mmol})$ was added [7]. The reaction was heated to $90^{\circ} \mathrm{C}$ and allowed to stir for $48 \mathrm{~h}$. The resulting mixture was cooled to $\mathrm{rt}$ and partitioned between DCM and water, followed by extraction of the aqueous layer with DCM. The combined organic layers were washed with brine, dried over $\mathrm{Na}_{2} \mathrm{SO}_{4}$, and concentrated under reduced pressure. Purification by flash column chromatography using 4\% DCM/hexanes afforded a yellow oil ( $0.139 \mathrm{~g}, 38 \%$ ). TLC: $9 \%$ DCM/hexanes, Rf $\approx 0.5 .1 \mathrm{H} \mathrm{NMR}$ $(400 \mathrm{MHz}, \mathrm{CDCl} 3) \delta 8.34(\mathrm{~d}, J=8.9 \mathrm{~Hz}, 2 \mathrm{H}), 8.28(\mathrm{~d}, J=9.0 \mathrm{~Hz}, 2 \mathrm{H})$, $7.92(\mathrm{~d}, J=2.2 \mathrm{~Hz}, 2 \mathrm{H}), 7.86(\mathrm{~d}, J=8.8 \mathrm{~Hz}, 2 \mathrm{H}), 7.21(\mathrm{dd}, J=9.0,2.2$ $\mathrm{Hz}, 2 \mathrm{H}), 4.31(\mathrm{~m}, 2 \mathrm{H}), 3.98(\mathrm{~m}, 2 \mathrm{H}), 1.92 \mathrm{~m}, 2 \mathrm{H}), 1.83-1.48(\mathrm{~m}, 8 \mathrm{H})$, $1.48-1.30(\mathrm{~m}, 8 \mathrm{H}), 1.03(\mathrm{td}, J=7.5,2.1 \mathrm{~Hz}, 6 \mathrm{H}), 0.95(\mathrm{dt}, J=6.6$, $3.3 \mathrm{~Hz}, 6 \mathrm{H}) .{ }^{13} \mathrm{C}$ NMR (101 MHz, $\left.\mathrm{CDCl}_{3}\right) \delta 144.86,133.12,131.60$, $130.43,129.13,129.03,126.79,126.79,125.32,124.01,121.42$, 76.97, 40.85, 30.66, 29.31, 24.07, 23.30, 14.28, 11.38 .

\section{3,4-Bis[(2-ethylhexyl)oxy]-8,13-bis(triisopropylsily- lethynyl)dibenzo[c,g]-phenanthrene (10)}

To a flask containing $\left[\mathrm{PdCl}_{2}\left(\mathrm{CH}_{3} \mathrm{CN}\right)_{2}\right](13.7 \mathrm{mg}, 0.0524 \mathrm{mmol})$, XPhos (0.153 g, $0.314 \mathrm{mmol}$ ), and $\mathrm{Cs}_{2} \mathrm{CO}_{3}$ (2.22 g, $6.81 \mathrm{mmol}$ ) was added a solution of 9 (0.791 g, $1.31 \mathrm{mmol})$ in anhydrous 1,4-dioxane (5.2 ml) [8]. The suspension was allowed to stir at $\mathrm{rt}$ for 25 min prior to the addition of (triisopropylsilyl)acetylene (1.22 $\mathrm{ml}, 5.24 \mathrm{mmol}$ ). The mixture was heated to $90^{\circ} \mathrm{C}$ and allowed to stir for $16 \mathrm{~h}$. After cooling to $\mathrm{rt}$, the reaction was diluted with water and extracted with DEE. The combined organic layers were washed with brine, dried over $\mathrm{Na}_{2} \mathrm{SO}_{4}$ and concentrated under reduced pressure. Purification by flash column chromatography using $20 \%$ hexanes/DCM as eluent afforded a yellow oil (0.940g, 80\%). TLC: $10 \%$ DCM/hexanes, $\mathrm{R}_{\mathrm{f}} \approx 0.6 .{ }^{1} \mathrm{H}$ NMR (400 MHz, $\mathrm{CDCl}_{3}$ ) $\delta 8.33$ (dd, $J=16.5,8.9 \mathrm{~Hz}, 4 \mathrm{H}), 8.14(\mathrm{~d}, J=1.7 \mathrm{~Hz}, 2 \mathrm{H}), 7.93(\mathrm{~d}, J=8.8 \mathrm{~Hz}, 2 \mathrm{H})$, $7.38(\mathrm{dd}, J=8.8,1.7 \mathrm{~Hz}, 2 \mathrm{H}), 4.36(\mathrm{~m}, 2 \mathrm{H}), 4.00(\mathrm{~m}, 2 \mathrm{H}), 1.96(\mathrm{~m}$, 2H), $1.83-1.55(\mathrm{~m}, 8 \mathrm{H}), 1.49-1.38(\mathrm{~m}, 8 \mathrm{H}), 1.24(\mathrm{~s}, 42 \mathrm{H}), 1.07(\mathrm{td}$, $J=7.4,2.1 \mathrm{~Hz}, 6 \mathrm{H}), 0.98$ (td, $J=7.0,2.0 \mathrm{~Hz}, 6 \mathrm{H}) .13 \mathrm{C} \mathrm{NMR}(101 \mathrm{MHz}$, $\mathrm{CDCl}_{3}$ ) $\delta 145.04,131.88,131.74,130.36,129.45,128.96,127.81$, 127.35, 124.29, 120.91, 120.81, 107.51, 91.35, 76.95, 40.89, 30.68, $29.34,24.11,23.34,18.93,14.30,11.60,11.41$.

\section{3,4-Bis((2-ethylhexyl)oxy)-8,13-diethynyldibenzo[c,g] phenanthrene (1)}

A solution of 10 (0.999 g, $1.12 \mathrm{mmol})$ in THF (22.3 ml) was cooled to $0{ }^{\circ} \mathrm{C}$ [9]. TBAF (1.0 M in THF) was added dropwise and the solution was allowed to warm to rt. After stirring for $16 \mathrm{~h}$, saturated aqueous $\mathrm{NaHCO}_{3}$ was added to the mixture, which was then extracted with DEE. The combined organic layers were washed with water, dried over $\mathrm{Na}_{2} \mathrm{SO}_{4}$ and concentrated under reduced pressure. Purification by flash column chromatography using $16 \%$ hexanes/DCM as eluent afforded a yellow oil (0.559 g, 96\%). TLC: $25 \%$ DCM/hexanes, $\mathrm{R}_{\mathrm{f}} \approx 0.7$. $1 \mathrm{H}$ NMR $\left(400 \mathrm{MHz}, \mathrm{CDCl}_{3}\right) \delta 8.36(\mathrm{~d}$, $J=8.8 \mathrm{~Hz}, 2 \mathrm{H}), 8.31(\mathrm{~d}, J=8.8 \mathrm{~Hz}, 2 \mathrm{H}), 8.14(\mathrm{~d}, J=1.8 \mathrm{~Hz}, 2 \mathrm{H}), 7.92$ $(\mathrm{d}, J=8.7 \mathrm{~Hz}, 2 \mathrm{H}), 7.36(\mathrm{dd}, J=8.8,1.5 \mathrm{~Hz}, 2 \mathrm{H}), 4.39-4.28(\mathrm{~m}, 2 \mathrm{H})$, $4.06-3.95$ (m, 2H), 3.20 (s, 2H), 1.99-1.92 (m, 2H), $1.85-1.52$ (m, 8H), 1.48-1.37 (m, 8H), 1.06 (td, J = 7.5, 2.2 Hz, 6H), $1.01-0.93(\mathrm{~m}$, 6H). 13C NMR (101 MHz, CDCl3) $\delta 145.09,132.18,131.65,130.55$, 129.58, 129.07, 127.59, 127.33, 124.17, 120.94, 119.46, 83.98, 77.89, 76.94, 40.84, 30.65, 29.31, 24.07, 23.30, 14.27, 11.38. UV-Vis absorption maxima: 258 ( $\varepsilon=83,300 \mathrm{~L} \mathrm{~mol}-1 \mathrm{~cm}-1), 325(\varepsilon=48,100$ $\left.\mathrm{L} \mathrm{mol}^{-1} \mathrm{~cm}^{-1}\right)$, and $368\left(\varepsilon=8,500 \mathrm{~L} \mathrm{~mol}^{-1} \mathrm{~cm}^{-1}\right) \mathrm{nm}$.

\section{3,4-Bis((2-ethylhexyl)oxy)-8,13-bis(phenylethynyl) dibenzo[c,g]phenanthrene (12)}

A flask charged with $2.11(72.5 \mathrm{mg}, 0.129 \mathrm{mmol})$, tetrakis(triphenylphosphine)palladium(0) (7.4 mg, $6.43 \mu \mathrm{mol})$, and copper(I) iodide $(1.2 \mathrm{mg}, 6.43 \mu \mathrm{mol})$ was brought up in THF $(1.3 \mathrm{ml}) .10$ Iodobenzene $(43.3 \mu \mathrm{l}, 0.387 \mathrm{mmol})$ and TEA $(0.77 \mathrm{ml})$ were then added and the reaction was allowed to stir at $40{ }^{\circ} \mathrm{C}$ for $16 \mathrm{~h}$. The reaction mixture was then cooled to $\mathrm{rt}$ and filtered with DCM through a short silica gel column, followed by concentration of the solvent under reduced pressure. Purification by flash column chromatography with $8 \%$ EtOAc/hexanes as eluent afforded a yellow oil (90.2 mg, 95\%) TLC: $17 \%$ EtOAc/hexanes, $\mathrm{R}_{\mathrm{f}} \approx 0.8 .1 \mathrm{H}$ NMR (400 MHz, $\left.\mathrm{CDCl}_{3}\right) \delta 8.33(\mathrm{~d}, J=8.8 \mathrm{~Hz}, 4 \mathrm{H}), 8.15(\mathrm{~d}, J=1.8 \mathrm{~Hz}$, 2H), $7.92(\mathrm{~d}, J=8.8 \mathrm{~Hz}, 2 \mathrm{H}), 7.64-7.55(\mathrm{~m}, 4 \mathrm{H}), 7.43-7.33(\mathrm{~m}$, $8 \mathrm{H}), 4.36-4.25(\mathrm{~m}, 2 \mathrm{H}), 4.01-3.95(\mathrm{~m}, 2 \mathrm{H}), 1.96-1.89(\mathrm{~m}, 2 \mathrm{H})$, $1.82-1.45(\mathrm{~m}, 8 \mathrm{H}), 1.45-1.32(\mathrm{~m}, 8 \mathrm{H}), 1.02(\mathrm{td}, J=7.5,2.1 \mathrm{~Hz}$, $6 \mathrm{H}), 0.94$ (ddt, $J=7.2,4.9,1.7 \mathrm{~Hz}, 6 \mathrm{H}) .{ }^{13} \mathrm{C} \mathrm{NMR}\left(101 \mathrm{MHz}, \mathrm{CDCl}_{3}\right.$ ) 
$\delta 145.06,131.83,131.81,131.34,130.29,129.45,129.12,128.53$, $128.44,127.39,124.27,123.46,120.87,120.64,90.26,89.83,76.96$ $40.85,30.66,29.31,24.08,23.31,14.28,11.39$.

UV-Vis absorption maxima: $283(\varepsilon=50,900 \mathrm{~L}$ mol- 1 $\mathrm{cm}-1), 332\left(\varepsilon=49,900 \mathrm{~L} \mathrm{~mol}^{-1} \mathrm{~cm}^{-1}\right)$, and $372(\varepsilon=17,700$ $\mathrm{L} \mathrm{mol}^{-1} \mathrm{~cm}^{-1}$ ) nm. Polymerization. A mixture of 2.11 (58.9 $\mathrm{mg}, 0.101 \mathrm{mmol})$, p-diiodobenzene $(33.7 \mathrm{mg}, 0.101 \mathrm{mmol}$ ), tetrakis(triphenylphosphine)palladium(0) (5.8 mg, $5.05 \mu \mathrm{mol}$ ), and copper(I) iodide $(1.0 \mathrm{mg}, 5.05 \mu \mathrm{mol})$ were dissolved in THF $(10 \mathrm{ml})$ and TEA $(6 \mathrm{ml}) .10$ The solution was heated to $40{ }^{\circ} \mathrm{C}$ and allowed to stir for $48 \mathrm{~h}$. Phenylacetylene (11 $\mu \mathrm{l}, 0.101 \mathrm{mmol})$ was then added and the solution continued to stir for $1 \mathrm{~h}$. The reaction was then cooled to rt and filtered through a short silica plug. The solvent was removed under reduced pressure and the resulting polymer was precipitated in $\mathrm{MeOH}$. The precipitated polymer was dried under high vacuum for $48 \mathrm{~h}$ at $60{ }^{\circ} \mathrm{C}$, resulting in $50.0 \mathrm{mg}$ (75\%) of an orange solid. $\mathrm{Mn}=4,411 \mathrm{~g} / \mathrm{mol}, \mathrm{Mw}=6,531 \mathrm{~g} / \mathrm{mol}$, PDI = 1.48. UV-Vis absorption maxima: $286\left(\varepsilon=57,100 \mathrm{~L} \mathrm{~mol}^{-1} \mathrm{~cm}^{-1}\right)$, $348\left(\varepsilon=85,100 \mathrm{~L} \mathrm{~mol}^{-1} \mathrm{~cm}^{-1}\right)$, and $382\left(\varepsilon=43,300 \mathrm{~L} \mathrm{~mol}^{-1} \mathrm{~cm}^{-1}\right) \mathrm{nm}$.

\section{Characterization}

SEC was performed on a Shimadzu HPLC system consisting of: a Shimadzu LC-20AT HPLC pump, a Rheodyne 7725i injector, Phenogel 5u 50 x $7.8 \mathrm{~mm}$ Guard Column, Polymer Laboratories PLgel $5 \mu \mathrm{m}$ MIXED-C column x 2, and a Shimadzu RID 10-A detector, at ambient temperature, using THF (HPLC grade) as the elution solvent with a flow rate of $1 \mathrm{ml} / \mathrm{min}$. Polystyrene standards were used for calibration (Figure 1). The absorbance spectra were recorded on an Agilent UV-Visible Spectrophotometer using a $1 \mathrm{~cm}$ trajectory and a blank cell $\left(\mathrm{CHCl}_{3}\right)$ for each sample. Monomer 2.1 (4.4 mg) was dissolved in $5 \mathrm{ml}$ of $\mathrm{CHCl}_{3}$ to make a stock solution $\left(3.69 \times 10^{-4} \mathrm{M}\right)$, which was then diluted to achieve an appropriate concentration for measurement $\left(1.42 \times 10^{-5} \mathrm{M}\right)$. Model monomer $2.14\left(1.6 \mathrm{mg}\right.$ ) was dissolved in $4 \mathrm{ml}$ of $\mathrm{CHCl}_{3}$ to make a stock solution (5.45 $\times 10-4 \mathrm{M})$, which was then diluted to achieve an appropriate concentration for measurement $\left(4.95 \times 10^{-5} \mathrm{M}\right)$. Polymer 2.15
(0.4 mg) was dissolved in $4 \mathrm{ml}$ of $\mathrm{CHCl}_{3}$ to make a stock solution $\left(2.01 \times 10^{-5} \mathrm{M}\right)$, which was then diluted to achieve an appropriate concentration for measurement $\left(1.82 \times 10^{-6} \mathrm{M}\right)$.

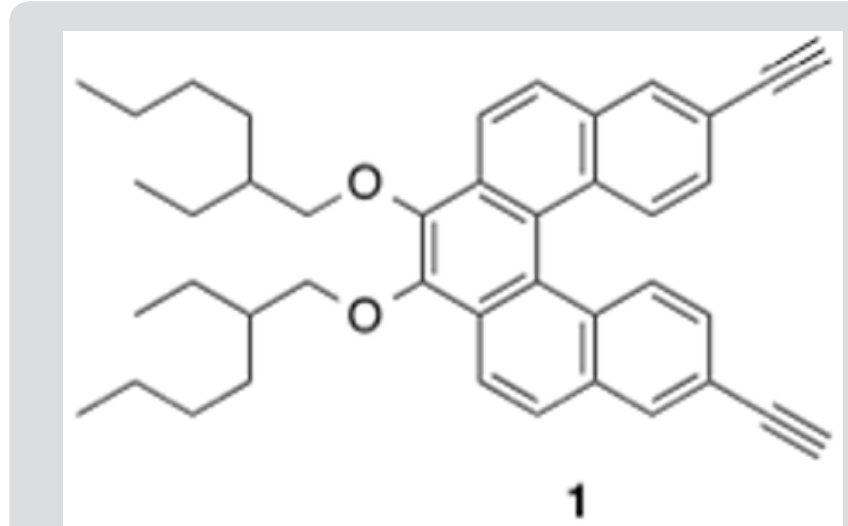

Figure 1: Target helicene monomer.

\section{Results and Discussion}

The synthesis of target structure 1 begins with the assembly of a Z,Z-stilbene (Scheme 2 \& Scheme 3), which is, in turn, the precursor for the $\mathrm{C}-\mathrm{H}$ arylation reaction (Scheme 5). The required triphenylphosphine salt 3 was synthesized (Scheme 3 ) by reaction of commercially available 2 with triphenylphosphine in near quantitative yield $[25,26]$. Dialdehyde 5 was prepared according to previous reports, via double directed ortho-lithiation of veratrole (4) [27]. The relatively low yield of this reaction could be due to the reduced solubility of the aryllithium intermediate or, possibly, secondary reactions, thus compromising the second lithiation [28]. Varying the conditions have not improved this low yield (Scheme 4). With both aldehyde 5 and triphenylphosphine salt 3 in hand, the two were combined under basic conditions to generate stilbene 6 (Scheme 2) in a ratio of 6:1 Z,Z:Z,E [16]. The subsequent conversion of 6 into 7, via a $\mathrm{Pd}(0)$-catalyzed double $\mathrm{C}-\mathrm{H}$ arylation reaction was accomplished in 63\% yield (Scheme 5). Because helicene 7 has limited solubility in many solvents, this intermediate was transformed into 9, having two 2-ethylhexyl groups [29].
(2)<smiles>O=P(Br)(Cc1cc(Cl)ccc1Br)c1ccccc1</smiles>

3<smiles>COc1c(C=O)ccc(C=O)c1OC</smiles>

5
KOt-Bu, THF: $\mathrm{H}_{2} \mathrm{O}(10: 1)$

$0{ }^{\circ} \mathrm{C}$ to rt, $30 \mathrm{~min}$

$68 \%$

$Z, Z: Z, E=6: 1$

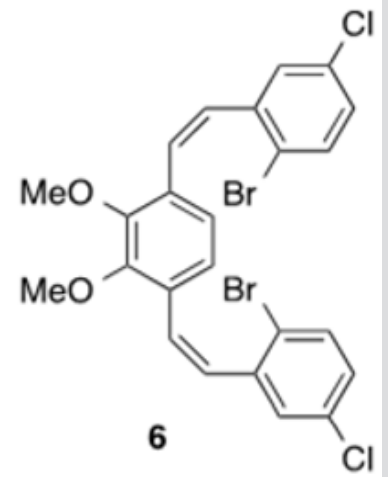

$\mathrm{Cl}$

Scheme 2: Preparation of the Z,Z-stilbene, 6 . 
<smiles>Clc1ccc(Br)c(CBr)c1</smiles>

2

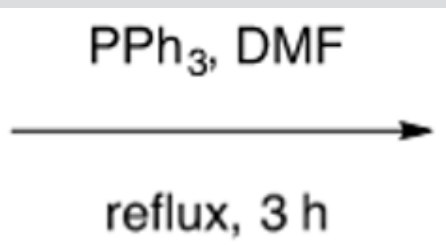

$98 \%$<smiles>Clc1ccc(Br)c(CP(Br)Br)c1</smiles>

3

Scheme 3: Preparation of the triphenylphosphine salt.

$\mathrm{MeO}$

$\mathrm{MeO}$<smiles>Ic1ccccc1I</smiles>

1. $n$-BuLi, TMEDA, DEE $-78^{\circ} \mathrm{C}$ to reflux, $16 \mathrm{~h}$

2. DMF, $-78^{\circ} \mathrm{C}$ to $\mathrm{rt}, 1 \mathrm{~h}$

$34 \%$

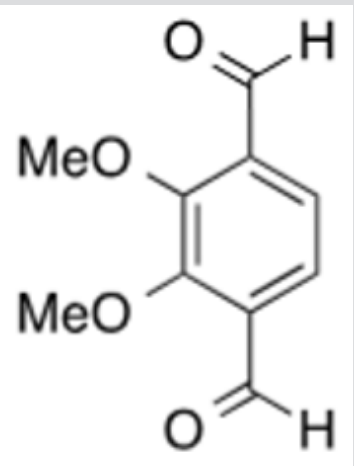

5

Scheme 4: Preparation of the dialdehyde.

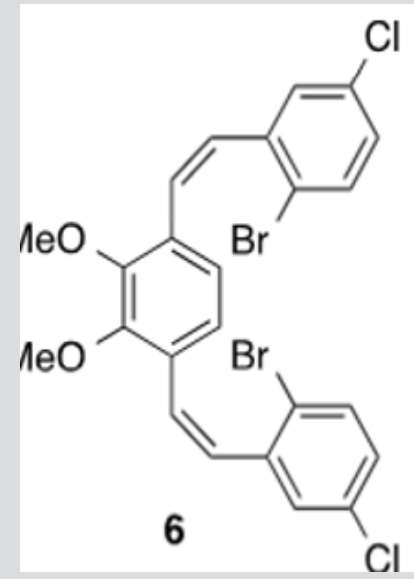

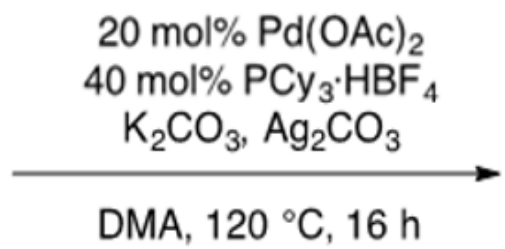

$63 \%$<smiles>COc1c(OC)c2ccc3cc(Cl)ccc3c2c2c1ccc1cc(Cl)ccc12</smiles>

7

Scheme 5: Palladium-mediated double C-H arylation reaction.

This was carried out by cleavage of the methoxy ether functionality using boron tribromide [30,31]. The resulting diol (8) was subsequently alkylated with 2-ethylhexyl bromide (Scheme 6). This reaction proceeded slowly, but with the inclusion of dibenzo-18-crown-6 as a catalyst, a moderate yield (38\%) of the alkylated product (9) was obtained as a viscous oil [32]. Compound 9 was significantly more soluble in common organic solvents in comparison with its precursor, 7. As pointed out above, the ability to vary the type of alkoxy group allows for a degree of leverage with respect to physical properties $[8,22]$. The last step in completing the helicene monomer 1 was the substitution of the two chlorinegs of 9 with alkyne groups that should allow copolymerization using Sonogashira conditions. Using the method reported by Buchwald [19], a Pd(II)-catalyzed substitution gave 10 having two TIPS-protected acetylene groups (Scheme 7). In this case, doubling the ratio of ligand to metal (6:1 rather than 3:1) was necessary for optimal yields. A tetrabutylammonium fluoridemediated deprotection of the TIPS groups gave monomer 1 in near quantitative yield [33]. 
<smiles>COc1c(OC)c2ccc3ccc(Cl)cc3c2c2c1ccc1cc(Cl)ccc12</smiles>

7

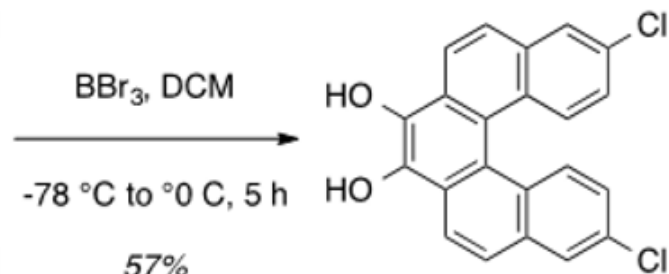

8<smiles>[R6]c1c(O)c2ccc3cc(Cl)ccc3c2c2c1ccc1cc(Cl)ccc12</smiles>

9

Scheme 6: Deprotection of the methoxy groups, followed by alkylation $(\mathrm{R}=2$-ethylhexyl).

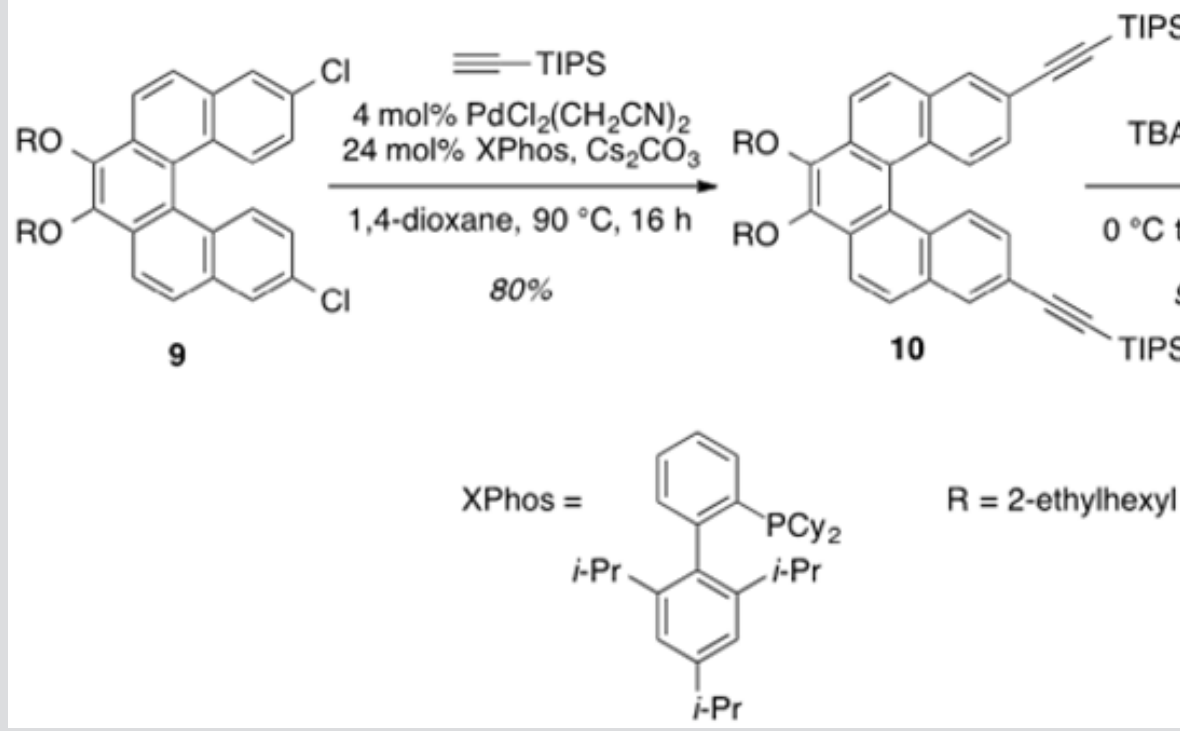

Scheme 7: Coupling of the TIPS-protected alkyne groups, followed by deprotection of the TIPS groups ( $\mathrm{R}=2$-ethylhexyl).

Monomer 1 was subjected to a Pd(0)-catalyzed Sonogashira reaction with $\mathrm{p}$-diiodobenzene in the presence of catalytic amounts of $\mathrm{Pd}\left(\mathrm{PPh}_{3}\right)_{4} \mathrm{Cl}$ and $\mathrm{CuI}$ in THF and TEA to afford polymer 11 in $80 \%$ yield [17]. This polymer was soluble in common organic solvents, including THF, DCM, and $\mathrm{CHCl}_{3}$ (Scheme 8). The numberaverage molecular weight $\left(M_{n}\right)$ was determined to be $4,411 \mathrm{~g} / \mathrm{mol}$ (PDI = 1.48) by SEC, using polystyrene standards in THF $[34,35]$. In addition, a model analogue 12 was synthesized by end-capping of 1 using similar reaction conditions, 16 allowing comparisons with polymer 11 (Scheme 9). As shown in Figure 2, the absorption maxima at 286, 348, and $382 \mathrm{~nm}$ of polymer 11 are red-shifted compared with model monomer 12 having maxima at 283, 332, and $372 \mathrm{~nm}$, with red shifts of 3,16 , and $12 \mathrm{~nm}$, respectively. These spectral differences are consistent with the extended partial $\pi$ conjugation [36]. This is significant, because extended conjugation is a desired characteristic in the design of many NLO and other organic materials $[37,38]$.

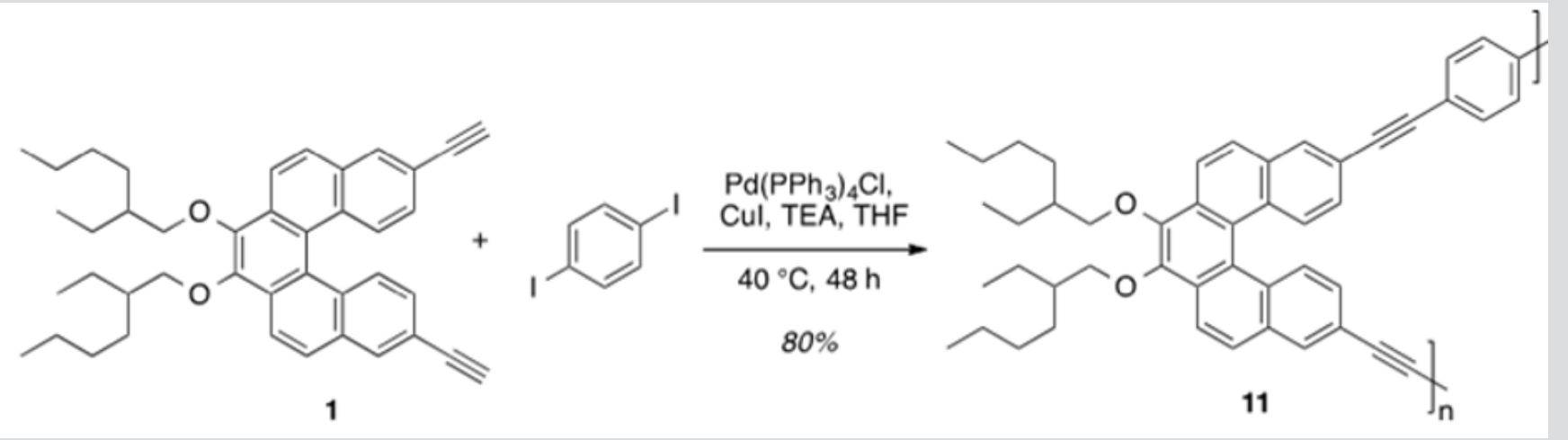

Scheme 8: Polymerization between the helicene monomer and p-diiodobenzene ( $R$ = 2-ethylhexyl). 
<smiles></smiles>

1
(2)<smiles>Ic1ccccc1</smiles>

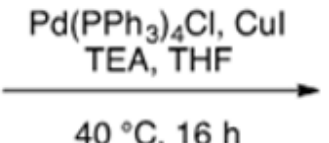

$40^{\circ} \mathrm{C}, 16 \mathrm{~h}$<smiles>[R6]c1c(O)c2ccc3cc(C#Cc4ccccc4)ccc3c2c2c1ccc1cc(C#Cc3ccccc3)ccc12</smiles>

Scheme 9: Synthesis of analogue $12(\mathrm{R}=2$-ethylhexyl).

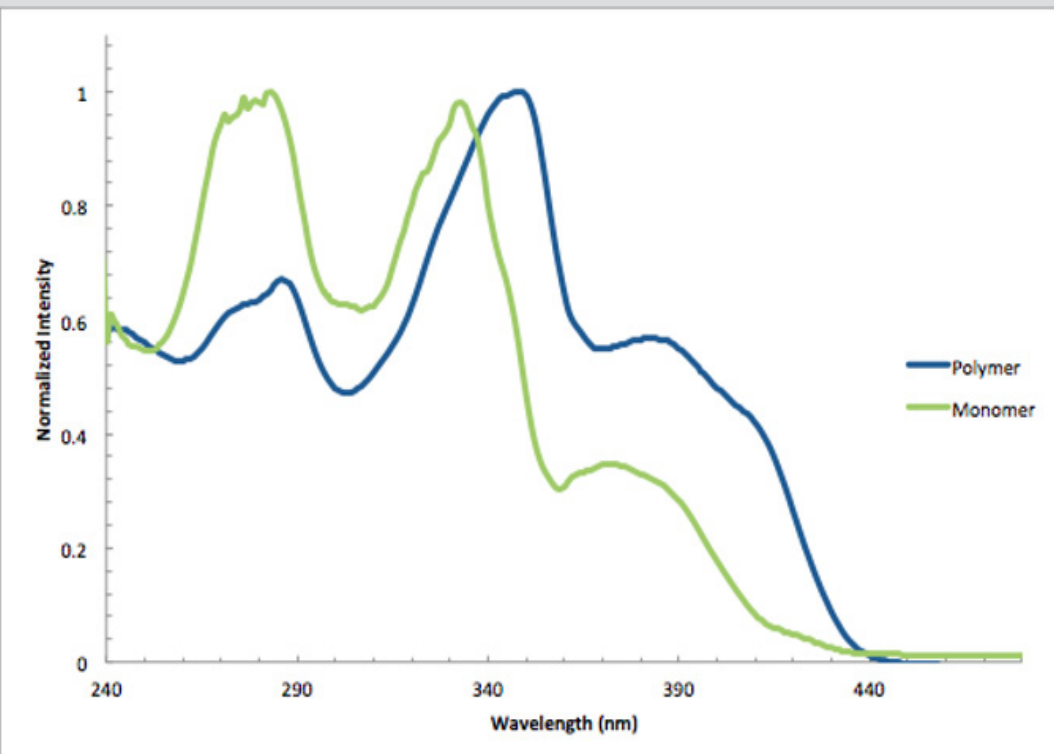

Figure 2: Normalized absorption spectra of polymer $11(348 \mathrm{~nm}, \varepsilon=85,100 \mathrm{~L} \mathrm{~mol}-1 \mathrm{~cm}-1)$ and model monomer $12(332 \mathrm{~nm}, \varepsilon=$ $49,900 \mathrm{~L} \mathrm{~mol}-1 \mathrm{~cm}-1$ ) in $\mathrm{CHCl} 3$ at $25^{\circ} \mathrm{C}$.

\section{Conclusion}

A 3,12-diethyenyl [5]helicene with electron-donating ether groups was prepared and copolymerized with an aryl connector to produce a polymer with extended conjugation. This is the first example of a polymerization of a helicene with modifiable electron-donating functionality. This variability opens up helicenes as potential tunable components in organic electronic materials. Efforts in our laboratory toward more conformationally stable helicene monomers are currently underway.

\section{Acknowledgment}

JO acknowledges support for this work by severasl Moulton fellowships by the Loker Hydrocarbon Research institute.

\section{References}

1. Balaban, Polycycl AT (2003) Aromat Compd 23: 277.

2. Newman MS, Lednicer DJ (1956) The Synthesis and Resolution of Hexahelicene $^{1}$. Am Chem Soc 78(18): 4765.
3. Gingras M, Félix G, Peresutti R (2013) One hundred years of helicene chemistry. Part 2: stereoselective syntheses and chiral separations of carbohelicenes. Chem Soc Rev 42(3): 1007-1050.

4. Yang Y, Da Costa RC, Fuchter MJ, Campbell AJ (2013) Circularly polarized light detection by a chiral organic semiconductor transistor. Nat Photonics 7(8): 634-638.

5. Hatakeyama T, Hashimoto S, Oba T, Nakamura MJ (2012) Am Chem Soc 134: 19600 .

6. Sahasithiwat S, Mophuang T, Menbangpung L, Kamtonwong S, Sooksimuang T (2010) Synthetic Metals 160: 1148.

7. Shi L, Liu Z, Dong G, Duan L, Qiu Y, et al. (2012) Chemistry 18: 8092.

8. Verbiest T, Elshocht SV, Kauranen M, Hellemans L, Snauwaert J (1998) Strong enhancement of nonlinear optical properties through supramolecular chirality. Science 282(5390): 913-915.

9. Martin RH, Baes M (1975) Helicenes: Photosyntheses of [11], [12] and [14]helicene. Tetrahedron 31(17): 2135-2137.

10. Mori K, Murase T, Fujita M (2015) One-step synthesis of [16]helicene. Angew Chem Int Ed 54(23): 6847-6851.

11. Dai Y, Katz TJ, Nichols DA (1996) Angewandte Chemie International Edition 35: 2109. 
12. Pu L Macromol (2000) Novel chiral conjugated macromolecules for potential electrical and optical applications. Rapid Commun 21(12): 795-809.

13. Pu L (1998) 1,1'-Binaphthyl Dimers, Oligomers, and Polymers: Molecular Recognition, Asymmetric Catalysis, and New Materials. Chem $\operatorname{Rev}$ 98(7): 2405-2494.

14. Takahira Y, Sugiusra H, Yamaguchi MJ (2006) Org Chem 71: 763.

15. Fox JM, LinD, Itagaki, Y, Fujita TJ (1998) Org Chem 63: 2031.

16. Kamikawa K, Takemoto I, Takemoto S, Matsuzaka HJ (2007) Org Chem 72: 7406.

17. Yuan WZ, Hu R, Lam JW Y, Xie N, Jim CK W, et al. (2012) Chemistry 18: 2847

18. Kondo K, Okuda M, Fujitani T (1993) Macromolecules 26: 7382.

19. Gelman D, Buchwald SL (2003) Efficient palladium-catalyzed coupling of aryl chlorides and tosylates with terminal alkynes: use of a copper cocatalyst inhibits the reaction. Angew Chem Int Ed Engl 42(48): 59935996.

20. Ma L, Hu QS, Musick KY, Vitharana D, Wu C, et al. (1996) Macromolecules 29: 5083.

21. Dalton L (2002) In Polymers for Photonics Applications I; Advances in Polymer Science; Springer Berlin Heidelberg p. 1-86.

22. Roncali J (1997) Synthetic Principles for Bandgap Control in Linear $\pi$-Conjugated Systems Chem Rev 97(1): 173-206.

23. Martin RH, Marchant MJ (1974) Thermal racemisation of hepta-, octa, and nonahelicene : Kinetic results, reaction path and experimental proofs that the racemisation of hexa- and heptahelicene does not involve an intramolecular double diels-alder reaction. Tetrahedron 30(2): $347-$ 349.

24. Stammel C, Fröhlich R, Wolff C, Wenck H, De Meijere A, et al. (1999) Synthesis and X-ray analysis of new [5] helicenes - HMO calculations on the photocyclization of the stilbene precursors[1]. European Journal of Organic Chemistry 7: 1709-1718.

25. John Plater MJ (1997) Fullerene tectonics. Part 2.1 Synthesis and pyrolysis of halogenated benzo[c]phenanthrenes. Chem Soc Perkin 1: 2903-2909.

\section{ISSN: 2574-1241}

DOI: 10.26717/BJSTR.2019.17.003019

Thieo E Hogen Esch. Biomed J Sci \& Tech Res

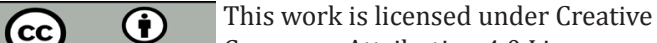

Submission Link: https://biomedres.us/submit-manuscript.php
26. Caruso A, Siegler MA, Tovar JD (2010) Synthesis of Functionalizable Boron-Containing $\pi$-Electron Materials that Incorporate Formally Aromatic Fused Borepin Rings. Angew Chem Int Ed 49(25): 4213-4217.

27. Kuhnert N, Rossignolo GM, Lopez Periago A (2003) The synthesis of trianglimines: on the scope and limitations of the $[3+3]$ cyclocondensation reaction between $(1 \mathrm{R}, 2 \mathrm{R})$-diaminocyclohexane and aromatic dicarboxaldehydes. Org Biomol Chem 1(7): 1157.

28. Crowther GP, Sundberg RJ, Sarpeshkar AM J (1984) Dilithiation of aromatic ethers. Org Chem 49(24): 4657-4663.

29. Padmanaban G, Ramakrishnan SJ (2000) Conjugation Length Control in Soluble Poly[2-methoxy-5-((2'-ethylhexyl)oxy)-1,4-phenylenevinylene] (MEHPPV): Synthesis, Optical Properties, and Energy Transfer. Am Chem Soc 122(10): 2244-2251.

30. Nakajima M, Miyoshi I, Kanayama K, Hashimoto SI J (1999) Copper (II) Schiff base catalysed aerobic oxidative couplingof 2-naphthols: an efficient and simple synthesis of binaphthols. Org Chem 64: 2264

31. Bandind M, Casolari S, Cozzi PG, Proni G, Schmohel E, et al. (2000) European Journal of Organic Chemistry 2000: 491.

32. Howard MJ, Heirtzler FR, Dias SI G (2008) Synthesis and Stereochemistry of Long-Chain Quinoxaline Metallocyclophanes. J Org Chem 73(7): 25482553.

33. Wipf P, Graham TH (2004) Otal Synthesis of (-)-Disorazole $\mathrm{C}_{1}$ J Am Chem Soc 126(47): 15346-15347.

34. Kokado K, Tokoro Y, Chujo Y (2009) Macromolecules 42(5): 9238.

35. Cheng H, Pu L (1999) Macromol Chem Phys.

36. Bédard AC, Vlassova A, Hernandez Perez AC, Bessette A, Hanan GS, et al. (2013) Synthesis, Crystal Structure and Photophysical Properties of Pyrene-Helicene Hybrids. Chemistry - A European Journal 19(48): 16295-16302.

37. Bendikov M, Wudl F, Perepichka DF (2004) Tetrathiafulvalenes, oligoacenenes, and their buckminsterfullerene derivatives: the brick and mortar of organic electronics. Chem Rev 104(11): 4891-4946.

38. Shen Y, Chen CF (2012) Helicenes: synthesis and applications. Chem Rev 112(3): 1463-1535

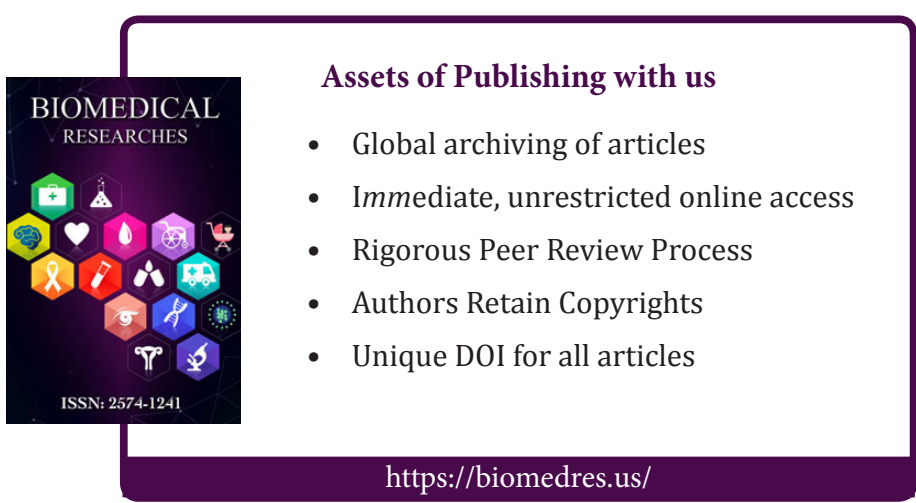

